\title{
A Study on the Definition of Some Biochemical Parameters and Oxidative Status According to Milk Yield in Cows
}

\author{
Neşe Hayat Aksoy ${ }^{1, a, *}$, Caner Öztürk²,b, Tahir Karaşahin ${ }^{3, c}$, Şükrü Dursun ${ }^{4, d}$ \\ ${ }^{1}$ Department of Biochemistry, Faculty of Veterinary Medicine, Aksaray University, 68100 Aksaray, Turkey \\ ${ }^{2}$ Department of Reproduction and Artificial Insemination, Faculty of Veterinary Medicine, Aksaray University, 68100 Aksaray, Turkey \\ ${ }^{3}$ Department of Physiology, Faculty of Veterinary Medicine, Aksaray University, 68100 Aksaray, Turkey \\ ${ }^{4}$ Department of Reproduction and Gyne-cology, Faculty of Veterinary Medicine, Aksaray University, 68100 Aksaray, Turkey
}

*Corresponding author

A R T I C L E IN F O A B S T R A C T

Research Article

Received : 11/06/2021

Accepted : 14/07/2021

\begin{abstract}
Our study, which investigates the factors affecting milk yield at metabolic and oxidative stress levels in Holstein breed cows raised in Aksaray Region, is the first at the regional level. It was aimed to perform biochemical and antioxidant screenings according to milk yield levels in healthy Holstein cows raised in the province, and thus, together with the determination of general metabolic parameters, the differences in total antioxidant and total oxidant levels according to milk yield were investigated. Glucose, total protein, albumin, globulin, total cholesterol, triglyceride, and calcium were analysed from blood samples taken from Holstein cows that have been determined to be healthy, in milk yield age in a province's enterprises were analysed by using commercial test kits in a semi-analyser device. Total antioxidant and total oxidant levels were analysed spectrophotometrically with commercial kits. Statistical analysis was made with Basic Statistics Xs Display Descriptive Statistics in Minitab 16

ready-made package program. Biochemical parameters studied in sera obtained from 5 different groups from the lowest to the highest were found to be statistically significant with a positive correlation. Total oxidant level, total antioxidant level and oxidative stress indices, in which the general oxidant status was screened, were found to be correlated with milk yield in proportion to the intense metabolic and physiological status of the animals and were found to be significant. With this study, the data obtained by eliminating a deficiency in this field both contribute to the literature knowledge in the scientific area and provide useful knowledge in the field.
\end{abstract}

Keywords:

Biochemical parameters Holstein

Total antioxidant level

Total oxidant level

Milk yield

\section{Introduction}

Blood is the liquid connective tissue that is an instant indicator of general health and nutritional status in humans and animals. It is well known that information about the biochemical parameters of blood and the physiological and pathological conditions of living things can be obtained (Coles, 1986; Ndlovu et al., 2007; Kaneko, 2008; Kaneko et al., 2008a-b; Maurya and Singh, 2016; Burtis and Ashwood, 2005). It is known that various variables such as nutritional status, stress, temperature, seasonal changes, living environmental conditions, diseases, metabolic activities, age, gender and race affect blood parameters and physiological values. Biochemical profiles provide reliable information on the health status of animals and also reflect the animal's responsiveness to its internal and external (Onasanya et al., 2015; Suttle, 2010; Kaneko et al., 2008a; Calbreath, 1992). Nutrient concentrations in blood tissue represent an integrated index of adequate nutrient supply in relation to the nutrient utilization of dairy cows. Metabolite levels in blood serum also indicate the extent of body metabolism such as energy, proteins and minerals (Ndlovu et al., 2007).

In the presented study, biochemical and oxidative stress parameters were investigated as very valuable biological tools to be used especially in order to confirm/control and monitor the health of lactating animals, to understand and monitor the effects of metabolic changes on milk yield and quality, and also to determine the effects of environmental conditions on lactating cows. Thus, total oxidant status (TOS) and total antioxidant status (TAS) were investigated, as well as biochemical parameters.

Free radicals are constantly formed as intermediates in catabolic enzymatic reactions in the cell. Reactive oxygen species (ROS) and reactive nitrogen species (RNS), known as intermediates, sometimes interact with molecular oxygen and form free oxygen radicals. These unstable oxygen species attack cells to become stable and cause various diseases by damaging the cell components. Molecular oxygen is an essential element for life and plays an important role in 
biological functioning thanks to its oxidative properties. Despite this, oxygen is like a double-edged sword and can damage healthy cells by causing oxidative events (Ozcan et al., 2015; Sezer and Keskin, 2014; Koca and Karadeniz, 2014; Kopáni et al., 2006; Kargin and Fidanc1, 1997; Jones, 2008). ROS react with lipids, proteins, carbohydrates and nucleic acids to gain electrons. Excessive production of free radicals and ROS can cause damage to all bio-macromolecules, especially in cell membrane components, and disruption of normal metabolism, physiology, and immunity (Trevisan et al., 2001; Vernon, 2002; Castillo et al., 2005; Castillo et al., 2006; Sordillo and Aitken, 2009). When the amount of these oxidants exceeds the capacity of the endogenous antioxidant system, they cause peroxidation of lipids in the membrane (which is the macromolecule most damaged by radicals), leading to impairment of vascular permeability and thus intracellular ion imbalance. It is well known that they also play an important role in the formation of many diseases by disrupting the structure of other macro-molecules (Kopáni et al., 2006; Castillo et al., 2005, 2006; Pintea et al., 2006; Sordillo et al., 2009; Sordillo and Aitken, 2009; Akpoyraz and Durak, 1995; Simsek, 1999; Tabakoğlu and Durgut, 2013; Ozcan et al., 2015). Endogenous (antioxidant enzymes) or exogenous (vitamins and minerals) defense structures that function to prevent the damage caused by ROS are "antioxidant defense systems". Antioxidants prevent lipid peroxidation by inhibiting the peroxidation chain reaction or by collecting ROS species. Antioxidants have a protective effect against cancer by reducing the effect of oxidative damage on DNA and the abnormal increase in cell division (Sezer and Keskin, 2014). The state of lipid peroxidation and free radical (ROS) release as a result of the shift of the balance between the antioxidant defense system and free radicals to the side of oxidants is called "oxidative stress" (Sezer and Keskin, 2014; Tabakoğlu and Durgut, 2013; Kopáni et al., 2006; Akpoyraz and Durak, 1995). It has been shown that oxidative stress may occur following biochemical changes (physiological or pathological), especially in lactating animals, during intense metabolic periods and contributes to some periparturive disorders or metabolic diseases (Bernabucci et al., 2002; Bernabucci et al., 2005). These harmful oxidant structures can cause periparturient period disorders in mammals with the effect of the oxidative stress (Abdellah, 2010 and 2016). In dairy cows, it is known that severe physiological changes and intense metabolic change periods create important metabolic activities especially in lipid and protein metabolism. The activity of all tissues and organs to respond to these intense metabolic demands is accompanied by a modification of energy metabolism and an increase in oxygen consumption. Intense biochemical and metabolic activity also causes an increment in the production of ROS, which are physiologically detoxified by antioxidant systems, which are the enzymatic and non-enzymatic defense mechanisms of living things (Castillo et al., 2005, 2006;
Pintea et al., 2006; Sordillo and Aitken, 2009). It is known that, the increasing of mitochondrial respiration because of the increase in energy demand, especially during lactation periods, also raises the synthesis of oxygen and free oxygen radicals (Castillo et al., 2005; Castillo, 2006).

Fatty liver, abomasum displacement, ketosis, retention secundinarium, hypocalcemia, downer cow syndrome (DCS), metritis and mastitis, etc., may be encountered frequently during the lactation period when the metabolism is intense. Both biochemical and oxidative status parameters are very useful in the follow-up of health, diagnosis and evaluation of diseases in animals in this process (Civelek, 2011). In the present study, TAS measurements have been significant assessment standard used to link antioxidant capacity, and TOS measurements were significant evaluation criteria used to establish a link between total oxidant status, with health status and disease risk. Thus, the oxidative status of lactating healthy holstein cows has been revealed against the total oxidant status content.

For the region-wide, in the literature, studies are quite insufficient in which biochemical parameters reflecting the general metabolic status of lactating Holstein cows are compared with oxidant-antioxidant levels. Its believed that, the results of this study in which whether there is a difference in total antioxidant and total oxidant levels according to milk yields and the oxidative stress index are determined, provides important clues in terms of animal health and milk yield.

\section{Material and Methods}

\section{Ethical Approval}

Kırıkkale University Experimental Animals Local Ethics Committee, (09.11.2017/17/07 - 17/43).

\section{Collection of Samples and Preparation for Analysis}

As the study material, blood samples taken from healthy cows (without any diseases in clinical examinations) were used from Holstein cow breeding and milk production enterprises in Aksaray province. The animals were evaluated in five groups according to their milk yield (Table 1). $15 \mathrm{~mL}$ of blood was taken from the vena jugularis. Serum was separated from clotted blood samples by centrifugation and hemolysis-free sera were stored at $-25^{\circ} \mathrm{C}$ till analysis (Coles, 1986).

\section{Assay of Biochemical Parameters}

The biochemical analyses of the samples (glucose, total protein, albumin, globulin, total cholesterol, triglyceride, calcium) were studied in a semi-analyser (Humalyzer3000-Semiautomated Benchtop Chemistry Photometer) device using commercial test kits in accordance with the kit procedures (Assel, Italy).

Table 1. Cow groups according to milk yield

\begin{tabular}{c|ccc}
\hline No & n & Groups & Milk Yields (L) \\
\hline $1-23$ & 23 & 1. Group & $5.9-19.9$ \\
$24-53$ & 30 & 2. Group & $20-25.1$ \\
$54-83$ & 30 & 3. Group & $25.2-30$ \\
$84-113$ & 30 & 4. Group & $30.3-34.7$ \\
$114-133$ & 20 & 5. Group & $35.4-47.3$ \\
\hline
\end{tabular}




\section{Assay of Oxidative Status Parameters}

Serum total antioxidant status (TAS) measurement was made according to the automatic measurement method developed by Erel (2004a, 2004b). Serum total oxidant status (TOS) was measured with commercial kits (REL Assay Diagnostic-Turkey) in accordance with the method developed by Erel (Erel, 2005). TAS and TOS values were read spectrophotometrically using ELISA plate reader (Elisa plate reader-Awareness Technology Chromate4300, USA). Oxidative stress index (OSI) was calculated by dividing the TOS values of the samples to the TAS values in percent (OSI (arbitrary unit, $\mathrm{AU})=((\mathrm{TOS}, \mu \mathrm{mol}$ $\mathrm{H}_{2} \mathrm{O}_{2}$ eq/L) / (TAS, $\mu$ mol Trolox eq/L)) (Yumru et al., 2009; Kosecik et al., 2005; Harma et al., 2003).

\section{Statistical Analysis}

Descriptive statistics of data obtained from biochemical and oxidative state analysis; it was made with Basic Statistics Xs Display Descriptive Statistics in Minitab 16 ready package program. Correlation analyses were evaluated with One Way Anova in the same package program. Data are given as arithmetic mean \pm standard error $(\mathrm{X} \pm \mathrm{SH})$. The statistical significance levels of the values were taken as $\mathrm{P}<0.05$.

\section{Results and Discussion}

Within the framework of the study, Holstein cows raised for milk production in Aksaray province were grouped as formed according to the different 30-day milk yields (Table 1). Biochemical (glucose, total protein, albumin, globulin, total cholesterol, triglyceride and calcium) and oxidant status parameters (TAS, TOS) in serum were measured according to milk yields. Milk yields; while there were statistically significant correlations in all these biochemical variables assayed in 5 different groups ranging from 5.9 to $47.3 \mathrm{~L}(\mathrm{P}=0.00)$, no statistically significant correlation was found in the calculated Alb/Glob ratio values ( $>>0.05$ ) (Table 2). And also, a positive correlation was found between serum TAS $(\mu \mathrm{mol} / \mathrm{L})$, TOS $(\mu \mathrm{mol} / \mathrm{L})$ and OSI $(\mu \mathrm{mol} / \mathrm{L})$ ratios and milk yield (Table 3 ) and determined a statistically significant relationship increased depending on the high milk yield $(\mathrm{P}=0.00)$.

Table 2. The correlation between milk yield and biochemical parameters

\begin{tabular}{|c|c|c|c|c|c|}
\hline Biochemical parameter & Milk yield (lt/day) & Groups & Mean & Std. Dev & $\mathrm{P}$ value \\
\hline \multirow{5}{*}{ Glucose (mg/dL) } & $5.9-19.9$ & 1. Group & 65.63 & 13.32 & \multirow{5}{*}{0.000} \\
\hline & $20-25.1$ & 2. Group & 78.16 & 12.64 & \\
\hline & $25.2-30$ & 3. Group & 87.71 & 9.69 & \\
\hline & $30.3-34.7$ & 4. Group & 98.21 & 10.37 & \\
\hline & $35.4-47.3$ & 5. Group & 129.48 & 31.20 & \\
\hline \multirow{5}{*}{ Protein (mg/dL) } & $5.9-19.9$ & 1. Group & 7.8522 & 0.7786 & \multirow{5}{*}{0.000} \\
\hline & $20-25.1$ & 2. Group & 7.1000 & 0.7325 & \\
\hline & $25.2-30$ & 3. Group & 6.5133 & 0.6585 & \\
\hline & $30.3-34.7$ & 4. Group & 6.4900 & 0.9650 & \\
\hline & $35.4-47.3$ & 5. Group & 6.4600 & 0.6824 & \\
\hline \multirow{5}{*}{ Albumin (mg/dL) } & $5.9-19.9$ & 1. Group & 3.8783 & 0.5485 & \multirow{5}{*}{0.000} \\
\hline & $20-25.1$ & 2. Group & 3.5367 & 0.4004 & \\
\hline & $25.2-30$ & 3. Group & 3.2167 & 0.3514 & \\
\hline & $30.3-34.7$ & 4. Group & 2.9557 & 0.3643 & \\
\hline & $35.4-47.3$ & 5. Group & 2.9271 & 0.3748 & \\
\hline \multirow{5}{*}{ Globulin (mg/dL) } & $5.9-19.9$ & 1. Group & 3.9639 & 0.4651 & \multirow{5}{*}{0.000} \\
\hline & $20-25.1$ & 2. Group & 3.5700 & 0.5881 & \\
\hline & $25.2-30$ & 3. Group & 3.2773 & 0.7642 & \\
\hline & $30.3-34.7$ & 4. Group & 3.5316 & 0.9113 & \\
\hline & $35.4-47.3$ & 5. Group & 3.5129 & 0.8265 & \\
\hline \multirow{5}{*}{$\mathrm{Alb} / \mathrm{Glb}(\mathrm{mg} / \mathrm{dL})$} & $5.9-19.9$ & 1. Group & 0.9978 & 0.2134 & \multirow{5}{*}{0.099} \\
\hline & $20-25.1$ & 2. Group & 1.0207 & 0.2186 & \\
\hline & $25.2-30$ & 3. Group & 1.0520 & 0.3251 & \\
\hline & $30.3-34.7$ & 4. Group & 0.9028 & 0.2979 & \\
\hline & $35.4-47.3$ & 5. Group & 0.8840 & 0.2484 & \\
\hline \multirow{5}{*}{ Total cholesterol (mg/dL) } & $5.9-19.9$ & 1. Group & 155.60 & 51.42 & \multirow{5}{*}{0.000} \\
\hline & $20-25.1$ & 2. Group & 277.42 & 45.18 & \\
\hline & $25.2-30$ & 3. Group & 323.54 & 21.53 & \\
\hline & $30.3-34.7$ & 4. Group & 331.59 & 40.60 & \\
\hline & $35.4-47.3$ & 5. Group & 347.49 & 43.31 & \\
\hline \multirow{5}{*}{ Triglyceride (mg/dL) } & $5.9-19.9$ & 1. Group & 122.85 & 13.67 & \multirow{5}{*}{0.000} \\
\hline & $20-25.1$ & 2. Group & 132.44 & 11.70 & \\
\hline & $25.2-30$ & 3. Group & 137.72 & 11.64 & \\
\hline & $30.3-34.7$ & 4. Group & 140.71 & 13.93 & \\
\hline & $35.4-47.3$ & 5. Group & 153.82 & 11.57 & \\
\hline \multirow{5}{*}{ Calcium (mg/dL) } & $5.9-19.9$ & 1. Group & 12.104 & 1.378 & \multirow{5}{*}{0.000} \\
\hline & $20-25.1$ & 2. Group & 10.453 & 0.947 & \\
\hline & $25.2-30$ & 3. Group & 9.893 & 0.766 & \\
\hline & $30.3-34.7$ & 4. Group & 9.117 & 0.925 & \\
\hline & $35.4-47.3$ & 5. Group & 8.865 & 0.576 & \\
\hline
\end{tabular}


Table 3. Correlation between milk yield and TAS, TOS and OSI parameters

\begin{tabular}{c|clccc}
\hline Oxidative status parameter & Milk yield (lt/day) & Groups & Mean & Std. Dev & P value \\
\hline & $5.9-19.9$ & 1. Group & 409.1 & 191.5 \\
& $20-25.1$ & 2. Group & 738.9 & 95.7 & \\
TAS $(\mu \mathrm{mol} / \mathrm{L})$ & $25.2-30$ & 3. Group & 1074.4 & 103.5 & 0.000 \\
& $30.3-34.7$ & 4. Group & 1285.4 & 148.8 \\
& $35.4-47.3$ & 5. Group & 1539.2 & 126.4 \\
\hline & $5.9-19.9$ & 1. Group & 30.17 & 13.11 \\
TOS $(\mu \mathrm{mol} / \mathrm{L})$ & $20-25.1$ & 2. Group & 38.16 & 16.54 & \\
& $25.2-30$ & 3. Group & 50.29 & 10.57 & 0.000 \\
& $30.3-34.7$ & 4. Group & 54.45 & 11.57 & \\
& $35.4-47.3$ & 5. Group & 68.01 & 14.03 & \\
& $5.9-19.9$ & 1. Group & 10.254 & 10.509 \\
OSI $(\mathrm{TOS} / \mathrm{TAS})$ & $20-25.1$ & 2. Group & 5.166 & 2.354 & \\
& $25.2-30$ & 3. Group & 4.748 & 1.169 \\
& $30.3-34.7$ & 4. Group & 4.250 & 0.826 \\
& $35.4-47.3$ & 5. Group & 4.412 & 0.788 & 0.000 \\
\hline
\end{tabular}

Accordingly, it is understood that serum glucose levels that increase as milk yield increases are directly proportional to the biochemical, metabolic mechanisms and physiological change intensities of the animals. In the protein panel, in parallel with the increase in milk secreting in all groups; decreased amount of serum total protein, albumin, globulin; it is compatible with catabolic biochemical processes where metabolite synthesis is intense during the lactation period and it is statistically significant $(\mathrm{P}=0.00)$. Similarly, it is not surprising that serum cholesterol and triglyceride levels were found to be significantly higher $(\mathrm{P}=0.00)$ starting from the first group in parallel with the increased milk yield in cows during lactation periods when intense metabolic processes occur (Table2, 3). It is milk secretion that is the main route of calcium loss from the body in mammals (Brini et al., 2013). Thus, it is an expected situation that the amount of calcium added to the milk from the body stores will decrease in the depots and serum during the lactation period. And in the study, it is an predicted result that the lowest serum calcium level in the groups is in the 5th group, which has the highest milk producing animals $(\mathrm{P}=0.00)$.

In response to very intense and heavy metabolic demands, the activities of all tissues and organs are accompanied by modification of producing biochemical mechanisms and increased oxygen consumption. This biochemical and metabolic movement also causes an increase in the production of reactive oxygen species (ROS), which are physiologically neutralized by endogenous "antioxidant systems", which are the enzymatic and non-enzymatic defense systems of living organisms. The imbalance between the rate of ROS production and their neutralization leads to oxidative stress (Trevisan et al., 2001; Turk et al., 2008). Total antioxidant potential or capacity is generally the ability of a tissue to resist oxidative stress induced by antioxidative mechanisms (Sordillo and Aitken, 2009; Valko et al., 2007). It is known that an imbalance between the rate of ROS production and the neutralization of reactive oxygen species leads to oxidative stress (OS) which plays an important role in various pathological conditions. In pathological conditions, an imbalance between increased production of ROS and decreased antioxidant capacity is observed (Trevisan et al., 2001; Pintea et al., 2006; Valko et al., 2007; Abdellah, 2010 and 2016). It is also wellknown that oxidative stress may occur during the transition period and contribute to some periparturative disorders or metabolic diseases (Bernabucci et al, 2002; Bernabucci et al, 2005). During the prenatal and early lactation period, changes occur especially in lipids and protein metabolism. The transition period is under strict hormonal control that coordinates the activity of all tissues and organs to respond to these metabolic demands (Vernon, 2002; Castillo et al., 2005; Castillo et al. 2006; Sordillo and Aitken, 2009; Turk et al., 2013). In the study groups; the increase in the amount of oxidant agents in proportion to the increasing amount of milk is a predictable result in mammalian physiology during the milk secretion process, where oxidative stress is intense. The increase of total oxidant levels in serum in direct proportion to milk yield was also found to be statistically significant $(\mathrm{P}=0.00)$. As a requirement of an intense physiological metabolic process such as milk secretion, anti-oxidant systems are expected to work at that rate against the oxidative stress caused by the total reactive oxidant derivatives formed in the body. It is observed that with this expected increased total antioxidant levels, the antioxidative defense works in a known way and increasing TAS rates against increasing TOS $(\mathrm{P}=0.00)$. In connection with these results, the decrease in the oxidative stress index (OSI) from the first group towards the end is also shown in our study as the second best evidence for the reduction of oxidative stress by antioxidant mechanisms, and therefore, that the total antioxidant mechanisms work in increasing amounts to detoxify the increased oxidant status. As a result, in the study, severe physiological changes and periods of intense metabolic change in dairy cows were directly proportional to the parameters expressing the oxidant status obtained, and the values in the serum were found to be statistically significant $(\mathrm{P}=0.00)$.

In the light of this information, the study was designed by focusing on the assumption that, the antioxidant systems and biochemical mechanisms will experience maximum stress in dairy cows, which is the research material, against the oxidant load brought by the intense metabolic period, during the periods when milk production is at its the highest level. Animals that were considered healthy in their detailed clinical examinations and detailed anamnesis participated in the study. The animals, which were divided into five groups 
according to milk yield differences, were kept under the same conditions, in the same farm, under the same feed control, under regular veterinary supervision. In dairy cows; in this metabolic process, which is known to have severe physiological changes and an intense metabolic change period, it has been demonstrated with the investigated parameters whether both biochemical and metabolic responses are provided with the oxidant-antioxidant balance in healthy animals. In this comparative study, in which homeostatic, metabolic and oxidative stress indexes were considered together, all the results were revealed as a result of the balance of properly functioning mechanisms in clinically healthy mammals. When the literature is reviewed, it is seen that these parameters are examined in disease states. It is known that severe metabolic and physiological changes in dairy cows create important energy activities in the anabolic-catabolic balance of all macromolecules, especially lipid and protein metabolism. To respond to these intense metabolic demands, the activity of all tissues and organs is accompanied by a modification of energy metabolism and an increase in oxygen consumption. It has been shown that oxidative stress may occur following biochemical changes (physiological or pathological), especially in lactating animals, during these excessive active metabolic periods, leading to some periparturative disorders or metabolic diseases (Bernabucci et al., 2002; Bernabucci et al., 2005). It was determined that the total antioxidative defense system against reactive oxygen radicals increased with the increase in milk yield in the groups and the oxidative stress index was suppressed and decreased. In addition, serum glucose elevation, which is a routine indicator of stress and intense energy metabolism, was found to be directly proportional to milk yield. It is known that glucose gives the first response by rising in the blood during periods of stress and intense metabolic mechanisms (Coles, 1986; Bishop et al., 2000; Kaneko et al. 2008-a). Dissimilar to our study; Castillo et al., (2006) investigated plasma MDA and total antioxidant levels, which are the degradation products of lipid peroxidation, in healthy Holstein dairy cattle, and found that plasma total antioxidant status peaked in the first week after calving and then decreased. In the study, this is attributed to the depletion of fat-soluble antioxidants, possibly due to milk production. It has been concluded that providing vitamin and mineral supplementation to cattle in the dry period, even if they do not show any clinical signs, will reduce the risk of disease. In addition, it has been suggested that MDA and TAS values, which are used to measure oxidant/antioxidant balance, can provide complementary information about the homeostasis of transitional cattle in addition to traditional metabolic parameters such as glucose and free fatty acids (Castillo et al., 2006). In another similar study, ROS, serum antioxidant capacity and oxidative stress index parameters were evaluated in high milk yielding bovine serums at different periods of the transition period, and no significant change was detected when ROS and serum antioxidant capacity values were compared with the control group at any stage. However, it was reported that the oxidative stress index was significantly higher than the control group during the peak period of lactation (Abuelo et al., 2013). Consistent with our study, in oxidant status studies conducted in lactating cows in different regions (Sordillo et al., 2009; AbdEllah et al., 2016), it was reported that the increase in oxygen requirement during increased metabolic demands resulted in increased ROS production. In addition, it is stated that the imbalance between the increase in ROS production and the antioxidant defense system in lactating cows increases oxidative stress, which is an important factor underlying immune and inflammatory disorders that increase susceptibility to diseases in cattle. Unlike our study, its tried to make this table understandable with the presence of diseases in animals used in these studies. In presented study, we claim that healthy dairy cattle are exposed to important metabolic and physiological adaptations during the transition from pregnancy to lactation and that they can cope with this situation by giving strong biochemical and antioxidative responses through to these adaptive mechanisms. As markers of oxidative protein damage; A study conducted in 2017, which aimed to evaluate the changes in plasma total antioxidant capacity and plasma total thiol concentration, and the end product of lipid peroxidation, malondialdehyde, in samples obtained at different times, was studied in primiparous cows. In this study, which was compared with cows with multiple births, was reported that the TAS rates were lower in cows that gave birth for the first time. Compared to milk yield in our grouping, as a result of this study, which contains close similarities, it is proposed that TAS may be a sensitive, reliable and useful indicator for the measurement of the cumulative effects of antioxidants, in addition to the metabolic profile tests that currently use to analyze dairy cattle health (Omidi et al., 2017). In this study, which was compared with cows that had multiple births, it was reported that the TAS rates were lower in cows that gave birth for the first time. Compared to milk yield in our grouping, this study, which contains close similarities, proposes that TAS may be a sensitive, reliable and useful indicator for the measurement of the cumulative effects of antioxidants in addition to the metabolic profile tests which currently use to analyze the dairy cattle' s health (Omidi et al., 2017). Similarly, we support the Castillo et al.' s views that oxidantantioxidant panels may will be add to the metabolic screening parameters, with the results of our study (Castillo et al., 2006). In addition, there are studies in the literature on different antioxidant agents, which show that oxidative stress increases during lactation periods in cows after calving, and investigate the possible relationships between oxidative stress, antioxidant nutrients and performance of peripartal dairy cows (Pintea et al., 2006; Castillo et al., 2005). In a study conducted in 2015, various biochemical parameters were compared in dairy cows (Sarker et al., 2015). It is seen that the protein, albumin and calcium values presented in the results are higher than the results we obtained, when milk yield is compared with the logic of our study. It was also observed that the glucose values were close to our first group with the lowest milk yield. In another study, contrary to our results, it was observed that protein and calcium levels increased and glucose decreased in lactating cows (Ndlovu et al., 2007). In the study conducted in some farms in Afyon, Turkey, in which the relationship between metabolic profile indicators and milk yield in different lactation stages in Holstein dairy cows was investigated; Glucose, cholesterol, total protein, total lipid, globulin, albumin, creatinine, $\mathrm{Mg}, \mathrm{Ca}, \mathrm{P}, \mathrm{AST}$ and ALT levels were investigated and it was emphasized that they positively affect milk productivity in animals (Polat et al., 2002). 
A different perspective can be brought with the balanced results obtained in our study, which can be evaluated as a response to the intense metabolic energy cycle and oxidative stress environment. It can be thought that the oxidative state, which is approached only with its toxic and harmful aspects in metabolism, may also be the protective mechanisms of the living thing as alarm systems that quickly activate the antioxidant systems at certain levels (Weidinger and Kozlov, 2015). In a study conducted in 2015 , it is recommended that oxidant agents should be handled more carefully as a double-edged sword. It is stated that which edge of the sword is dominant depends on the delicate balance between the production of reactive oxygen / nitrogen species and the antioxidant capacity of the tissue, the physiological functions of free radicals have been neglected for years and only the pathological activity of oxidative stress has been focused on. In the study, it is reminded that a wide variety of free radicals are constantly produced in cellular cycles in organisms and that they can interact with various substrates to provide a panel of biomarkers that can be used to assess the damage caused by oxidative stress (Frijhoff et al., 2015). With the results of the completed study, we think that lactating cows can generally manage free radical production with sufficient antioxidant reserves, but oxidative stress may occur in case of a large imbalance between ROS production and the availability of antioxidant molecules. As this general biochemical picture observed in the studied groups explains, the expected results in the study with healthy holstein cows are promising. Biochemical parameters, which are the most obvious indicators of animal health and general quality of life scale, explain this situation to us at serum level. In this study, the health status of animals is also valuable as a reflection of biochemical and physiological processes, as a proof of how they guide us. In summary, according to all this information, of course that biochemical screenings are necessary to identify numerous pathological, physiological and metabolic problems of dairy animals, as well as to monitor the treatment applied. In addition to biochemical parameters, we believe that metabolic profiles such as antioxidative/prooxidative status may be among the parameters that can be used routinely. Based on the data supported by such studies, it may become routine to add antioxidant preparations/food supplements to feed as preventive and therapeutic supplements in veterinary medicine in maintaining health and fighting diseases.

Protection of animal health; it is very important for the continuity of milk yield and keeping the yield high. In general, screening of the factors affecting milk yield will allow to address the better aspects of the situation. Dairy cattle and milk production have an important place in our country's economy. Aksaray province has a remarkable position in terms of dairy cattle and milk production, which have an important place in our country' s economy. No study was found in which biochemical parameters reflecting the general metabolic status were compared with antioxidant levels in Holsteins grown in our region. In addition, studies investigating the effects of antioxidant activity, oxidant level and biochemical differences on milk yield in general are quite inadequate in the literature. In our study, in this intense metabolic process where the milk yield is increased and challenging conditions are experienced; when both biochemical and oxidant/antioxidant values in animals classified in five groups were examined, it was once again demonstrated by the results obtained that a healthy metabolic antioxidative balance was achieved.

\section{Acknowledgment}

This study was financed by Aksaray University Scientific Research Projects Coordination Unit (P No: 2018-016).

\section{References}

AbdEllah MR. 2010. Involvement of free radicals in animal diseases. Comparative Clinical Pathology, 19 (6): 615-9.

AbdEllah MR. 2016. Oxidant and Antioxidants During the Transition Period in Dairy Cows. Journal of Advanced Veterinary Research, 6 (4): 130-133.

Abuelo A, Hernández J, Benedito JL, Castillo C. 2013. Oxidative stress index (OSi) as a new tool to assess redox status in dairy cattle during the transition period. Animal, 7 (8): 1374-78.

Akpoyraz M, Durak İ. 1995. Biological effects of free radicals. Journal of Ankara University Faculty Medicine, 48: 253-62.

Bernabucci U, Ronchi B, Lacetera N, Nardone A. 2002. Markers of oxidative status in plasma and erythrocytes of transition dairy cows during hot season. Journal of Dairy Science, 85 (9): 2173-9.

Bernabucci U, Ronchi B, Lacetera N, Nardone A. 2005. Influence of body condition on relationships between metabolic status and oxidative stress in periparturient dairy cows. Journal of Dairy Science, 88: 2017-2026.

Bishop ML, Duben-Engelkirk JL, Fody EP. 2000. Clinical Chemistry Principles, Procedures, Correlations, Lippincott Williams \& Wilkins, Philadelphia.

Brini M, Cali T, Ottolini D, Carafoli E. 2013. Intracellular calcium homeostasis and signaling. Metal Ions in Life Sciences,12: 119-68. (doi: 10.1007/978-94-007-5561-1-5.)

Burtis CA, Ashwood ER. 2005. Tietz, Klinik Kimyada Temel İlkeler. Beşinci Baskıdan Çeviri. Çeviri Editörü: Prof.Dr. Diler Aslan. Palme Yayıncilık. Ankara.

Calbreath DF. 1992. Clinical Chemistry A Fundamental Textbook. W.B. Saunders Company, Philadelphia.

Castillo C, Hernandez J, Bravo A, Lopez-Alonso M, Pereira V, Benedito JL. 2005. Oxidative status during late pregnancy and early lactation in dairy cows. The Veterinary Journal, 169 (2): 286-292. doi: 10.1016/j.tvjl.2004.02.001. PMID: 15727923.

Castillo C, Hernández J, Valverde I, Pereira V, Sotillo J, Alonso ML, Benedito JL. 2006. Plasma malonaldehyde (MDA) and total antioxidant status (TAS) during lactation in dairy cows. Research in Veterinary Science, 80 (2): 133-139. doi: 10.1016/j.rvsc.2005.06.003. Epub 2005 Aug 9. PMID: 16084546.

Coles EH. 1986. Veterinary Clinical Pathology (4th edition). W.B Saunders Co., Philadelphia. pp.10-79.

Civelek T. 2011. Süt Sığırlarında Periparturient Dönem Hastalıklar ve Karaciğer Fonksiyonu Üzerine Etkileri. Turkiye Klinikleri Journal of Veterinary Sciences Journal Identity, 2 (2): 131-139.

Erel O. 2004a. A novel automated method to measure total antioxidant response against potent free radical reactions. Clinical Biochemistry, $37 \quad$ (2): 112-9. doi: 10.1016/j.clinbiochem.2003.10.014. PMID: 14725941.

Erel O. 2004b. A novel automated direct measurement method for total antioxidant capacity using a new generation, more stable ABTS radical cation. Clinical Biochemistry, 37 (4): 277-85. doi: 10.1016/j.clinbiochem.2003.11.015. PMID: 15003729 . 
Erel O. 2005. A new automated colorimetric method for measuring total oxidant status. Clinical Biochemistry, 38: 1103-11.

Frijhoff J, Winyard PG, Zarkovic N, Davies SS, Stocker R, Cheng D, Knight AR, Taylor EL, Oettrich J, Ruskovska T, Gasparovic AC, Cuadrado A, Weber D, Poulsen HE, Grune T, Schmidt HH, Ghezzi P. 2015. Clinical relevance of biomarkers of oxidative stress. Antioxidants \& Redox Signaling, 23 (14): 1144-1170. Doi: 10.1089/ars.2015.6317.

Harma M, Harma M, Erel O. 2003. Increased oxidative stress in patients with hydatidiform mole. Swiss Medical Weekly, 133: $563-536$.

Jones DP. 2008. Radical-free biology of oxidative stress. The American Journal of Physiology-Cell Physiology, 295 (4): C849-68.

Kaneko JJ. 2008. Chapter:3: Carbohydrate Metabolism and Its Diseases. Clinical Biochemistry of Domestic Animals. 6th Edition Academic Press, Elsevier, pp. 45-80 (ISBN: 978-012-370491-7).

Kaneko JJ, Harvey JW, Bruss ML. 2008a. Clinical Biochemistry of Domestic Animals. 6th Edition. Academic Press N.Y.

Kaneko JJ, Harvey JW, Bruss ML. 2008b. Clinical Biochemistry of Domestic Animals. 6th Edition. Academic Press N.Y. pp. 663-693: Trace Minerals.

Kargin F, Fidancı UR. 1997. Free oxygen radicals and oxidative damage. Türk Veteriner Hekimliği Dergisi, 9 (2): 26-8.

Koca N, Karadeniz F. 2003. Production mechanisms of free radical and antioxidant defence systems in the body. Gida Mühendisliği Dergisi, 16: 32-7.

Kopáni M, Celec P, Danisovic L, Michalka P, and Biró C. 2006. Oxidative stress and electron spin resonance. Clinica Chimica Acta, 364: 61-66. (doi: 10.1016/j.cca.2005.05.016).

Kosecik M, Erel O, Sevinc E, Selek S. 2005. Increased oxidative stress in children exposed to passive smoking. International Journal of Cardiology, 100: 61-4.

Maurya SK, Singh OP. 2016. Blood Biochemical Profile and Nutritional Status of Dairy Cows under Field Conditions. Journal of Animal Research, 6 (1): 167-170.

Ndlovu T, Chimonyo M, Okoh AI, Muchenje V, Dzama K, Raats JG. 2007. Assessing the nutritional status of beef cattle: current practices and future prospects. African Journal of Biotechnology, 6 (24): 2727-2734.

Omidi A, Fathi MH, Parker MO. 2017. Alterations of antioxidant status markers in dairy cows during lactation and in the dry period. Journal of Dairy Research, 84: 49-53.

Onasanya GO, Oke FO, Sanni TM, Muhammad AI. 2015. Parameters Influencing Haematological, Serum and BioChemical References in Livestock Animals under Different Management Systems. Open Journal of Veterinary Medicine, 5: 181-189. http://dx.doi.org/10.4236/ojvm.2015.58025.

Ozcan O, Erdal H, Çakırca G, Yönden Z. 2015. Oxidative stress and its impacts on intracellular lipids, proteins and DNA. Journal of Clinical and Experimental Investigations, 6 (3): 331-336.

Pintea A, Daniela Z, Pop R Al, Sanda A, Kiss E, 2006. Antioxidant status in dairy cows during lactation. Bulletin of the University of Agricultural Sciences and Veterinary Medicine Cluj-Napoca Agriculture, 63: 130-135.
Polat Ü, Çetin M, Yalçın, A. 2002. Yüksek Verimli Süt ineklerinde Laktasyonun Çeşitli Evrelerinde Kandaki Bazı Biyokimyasal Parametreler ile Süt Verimi Arasındaki İlişkiler. Uludag University Journal of Research in Veterinary Medicine, 21: 65-69.

Sarker MS, Ahaduzzaman M, Sayeed MA, Sarker R, Nanno M, Mannan A, Hossain MB. 2015. Comparison of some serum biochemical parameters between lactating and non-lactating dairy cows in selected dairy farms of Chittagong district of Bangladesh. Asian Journal of Medical and Biological $\begin{array}{llll}\text { Research, } & 1 & \text { (2): } & \text { 259-264. }\end{array}$ DOI:https://doi.org/10.3329/ajmbr.v1i2.25620.

Sezer K, Keskin M. 2014. Role of the free oxygen radicals on the pathogenesis of the diseases. FÜ Sağlık Bilimleri Veteriner Dergisi, 28 (1): 49-56.

Simsek F. 1999. Free radicals, antioxidants and lipid peroxidation. Turkiye Klinikleri Journal of Pediatrics, 8 (1): 42-47.

Sordillo LM, Aitken SL. 2009. Impact of oxidative stress on the health and immune function of dairy cattle. Veterinary Immunology and Immunopathology, 128 (1-3): 104-9.

Sordillo LM, Contreras GA, Aitken SL. 2009. Metabolic factors affecting the inflammatory response of periparturient dairy cows. Animal Health Research Reviews, 10 (1): 53-63.

Suttle NF. 2010. Mineral Nutrition of Livestock, 4th the fertility of rams II. Macro and microscopic changes in the Edition. Cabi Publishing, USA. pp. 54, 122-354. http://dx.doi.org/10.1079/9781845934729.0000.

Tabakoğlu E, Durgut R. 2013. Oxidative stress in veterinary medicine and effects in some important diseases. AVKAE Dergisi, 3 (1): 69-75.

Trevisan M, Browne R, Ram M, Muti P, Freundenheim J, Carosella AN, Armstrong D. 2001. Correlates of markers of oxidative status in the general population. American Journal of Epidemiology, 154: 348-356.

Turk R, Juretić D, Geres D, Svetina A, Turk N, Flegar-Mestrić Z. 2008. Influence of oxidative stress and metabolic adaptation on PON1 activity and MDA level in transition dairy cows. Animal Reproduction Science, 108 (1-2): 98-106.

Turk R, Podpečan O, Mrkun J, Kosec M, Flegar-Meštrić Z, Perkov S, et al. 2013. Lipid mobilisation and oxidative stress as metabolic adaptation processes in dairy heifers during transition period. Animal Reproduction Science, 141 (3-4): 109-15.

Valko M, Leibfritz D, Moncol J, Cronin MT, Mazur M, Telser J. 2007. Free radicals and antioxidants in normal physiological functions and human disease. The International Journal of Biochemistry \& Cell Biology, 39 (1): 44-84.

Vernon, RG. 2002. Nutrient partitioning, lipid metabolism and relevant imbalances. In: Kaske M, Scholz H, Ho"ltershinken M. (Eds.), Recent Deveolpments and Perspectives in Bovine Medicine. Klinik für Rinderkrankheiten, Tiera"rztliche Hochschule, Hannover, pp:210-223.

Weidinger A, Kozlov AV. 2015. Biological activities of reactive oxygen and nitrogen species: oxidative stress versus signal transduction. Biomolecules, 5: 472-484. doi: 10.3390/biom5020472.

Yumru M, Savas HA, Kalenderoglu A, Bulut M, Celik H, Erel O. 2009. Oxidative imbalance in bipolar disorder subtypes: a comparative study. Progress in NeuroPsychopharmacology\&Biological Psychiatry, 33 (6): 1070-4. Doi: 10.1016/j.pnpbp.2009.06.005. 